\title{
PENGARUH KEPEMIMPINAN GURU TERHADAP DISIPLIN BELAJAR PESERTA DIDIK
}

\author{
THE EFFECT OF TEACHER LEADERSHIP ON LEARNING DISCIPLINE OF STUDENTS \\ R Rais'a, A Mahrudin'1, dan A Ilyas \\ 1 Program Studi Manajemen Pendidikan Islam, Fakultas Keguruan dan Ilmu Pendidikan, \\ Universitas Djuanda Bogor, Jl. Tol Ciawi No. 1 Kotak Pos 35 Ciawi Bogor 16720 \\ a Korespondensi: Riki Rais, Email: rickkirei@gmail.com \\ (Diterima: 19-09-2018; Ditelaah: 20-09-2018; Disetujui: 29-10-2018)
}

\begin{abstract}
The Effect of Teacher Leadership on Learning Discipline of students in MTS Tarbiyatul Huda Bogor. The discipline of learning from the adherence (compliance) learners against the rules (code of counduct) related to the teaching and learning activitis in schools, which include the time in and out of school, the students dressed in compliance, compliance learners in the following activities of the school. The discipline of learning does not arise by several factors, one of which, namely environmental factors of school teacher's leadership because when good leadership, it will be a positive effect on the deed and vice versa, as well as leadership and discipline the learners learn in MTS Tarbiyatul Huda Pancawati Bogor this research aims to know the level of teacher's leadership, the level of discipline of study and to find out whether or not there is the effect of teacher's leadership against the didiscipline of learning to learners. This research is quantitative research. The population in the study i.e learners class VII and VIII MTS Tarbiyatul Huda Pancawati Bogor. Which consists of 2 classes that amounted to 133 students. Sampel research as much as 58 leaners in specified using proportional random sampling. Variabel research include leadership of a teacher as free variable, and the variable learning as related disciplines. Using data collection techniques of observation, interview, question form, and documentation. Tes prasyrat analiysis of the date indicates that the Gaussian and linear hypothesis testing techniqus so that using simple regression. This study showed that: the existence of significant influence among the leadership of teacher against a disciplined learning through calculation analysis test $\mathrm{T}$ which yields thitung $(117,884)>$ ttabel $(1,672)$. Then the $\mathrm{H} 0$ is rejected and accepted $\mathrm{H} 1$ there is influence significant techer leadership against disciplined learning learners. The magnitude of contribution of the influence of the variabel X (teacher's leadership) against the variabel Y (study discipline) is $99,6 \%$ Whereas $13.6 \%$ are influenced by other factors not addressed in the study starting on the dotted research result, then all parties both teachers and parents should improve leadership and guidance to the students so that students can achieve the expected learning achiements.
\end{abstract}

Keywords: discipline of studets, the effect of teacher learning.

\section{ABSTRAK}

Disiplin belajar dapat dilihat dari ketaatan (kepatuhan) peserta didik terhadap aturan (tata tertib) yang berkaitan dengan kegitan belajar mengajar di sekolah, yang meliputi waktu masuk dan keluar sekolah, kepatuhan peserta didik dalam berpakaian, kepatuhan peserta didik dalam mengikuti kegiatan sekolah. Disiplin belajar tidak timbul dengan sendirinya, akan tetapi dipengaruhi oleh beberapa faktor, salah satunya yaitu faktor lingkungan sekolah dari kepemimpinan guru karena apabila kepemimpinan baik, maka akan berpengaruh terhadap perbuatan yang positif dan begitu pula sebaliknya, seperti halnya kepemimpinan 
dan disiplin belajar peserta didik di MTS Tarbiyatul Huda Pancawati Bogor. Penelitian ini bertujuan untuk mengetahui tingkat kepemimpinan guru, tingkat disiplin belajar dan untuk mengetahui ada tidaknya pengaruh kepemimpinan guru terhadap disiplin belajar peserta didik.Penelitian ini merupakan penelitian kuantitatif. Populasi dalam penelitian yaitu peserta didik kelas VII DAN VIII MTS Tarbiyatul Huda Pancawati Bogor yang terdiri dari 2 kelas yang berjumlah 133 peserta didik. Sampel penelitian sebanyak 58 peserta didik yang ditentukan menggunakan teknik Proporsional Random Sampling. Variabel penelitian meliputi kepemimpinan guru sebagai variabel bebas dan disiplin belajar sebagai variabel terikat. Teknik pengumpulan data menggunakan observasi, wawancara, angket dan dokumentasi. Uji prasyarat analisis menunjukkan bahwa data berdistribusi normal dan linear sehingga teknik pengujian hipotesis menggunakan analisis regresi sederhana.Hasil penelitian menunjukkan bahwa: adanya pengaruh yang signifikan antara kepemimpinan guru terhadap disiplin belajar peserta didik. Hal ini diperoleh melalui perhitungan analisis uji t yang menghasilkan $t_{\text {hitung }}(117,884)>t_{\text {tabel }}(1,672)$ maka $\mathrm{H}_{0}$ ditolak dan $\mathrm{H}_{1}$ diterima artinya terdapat pengaruh yang signifikan kepemimpinan guru terhadap disiplin belajar peserta didik. Besarnya sumbangan pengaruh yang diberikan variabel X (Kepemimpinan Guru) terhadap variabel Y (Disiplin Belajar) adalah 99,6\% sedangkan 0,04\% dipengaruhi oleh faktor lain yang tidak dibahas dalam penelitian. Bertitik tolak pada hasil penelitian, maka semua pihak baik guru dan orang tua hendaknya memperhatikan dan meningkatkan kepemimpinan dan bimbingan kepada peserta didik sehingga peserta didik dapat mencapai prestasi belajar yang diharapkan.

Kata kunci: disiplin belajar peserta didik, kepemimpinan guru.

Rais, R., Mahrudin, A., \& Ilyas, A. (2018). Pengaruh Kepemimpinan Guru Terhadap Disiplin Belajar Peserta Didik. Tadbir Muwahhid, 2(2), 144-155.

\section{PENDAHULUAN}

Guru merupakan pemimpin dalam aktivitas belajar, yang disebut sebagai direktur belajar (director of learning). Guru membimbing dan mengarahkan peserta didiknya untuk tumbuh menjadi pembelajar. Dia harus memiliki enenrgi pengaruh pada peserta didiknya. Energy pengaruh ini merukan cerminan dan sifiatsifat kepemimpinan yang dimilikinya.

Permasalahan yang muncul dalam kelas memang telah biasa terjadi, namun permasalahan tersebut tidak boleh dibiarkan begitu saja. Sekecil apapun permasalahan dalam kelas, dapat mengganggu keberlangsungan proses pembelajaran. Efek dari permasalahan yang muncul dapat berupa terhambatnya kegiatan pembelajaran, pembelajaran menjadi kurang efektif, bahkan peserta didik dapat kehilangan konsentrasi dalam belajar, tujuan pembelajaran tidak tercapai dengan sempurna. Sehingga pada akhirnya dapat berpengaruh pada prestasi belajar peserta didik. Berdasarkan hasil obeservasi dan wawancara langsung dengan Kepala Sekolah di MTS TARBIAYATUL HUDA diperoleh informasi bahwa guru dalam melaksanakan tugasnya ada yang memiliki kinerja baik dimana guru sudah menerapkan kedisiplinan terhadap siswa dan cara memimpin dalam proses pembelajaran. Namun ada juga kinerja guru yang masih harus ditingkatkan dalam melaksanakan kedisiplinan dan cara memimpin kelas dalam proses pembelajaran. Guru berperan besar terhadap kedisiplinan siswa di kelas. Guru tidak hanya dituntut untuk mengajar saja. Tetapi guru dituntut untuk untuk menjadi ahli penyebar informasi yang baik, karena 
tugas utamanya antara lain menyampaikan informasi kepada peserta didik penyampaian informasi ini sangat penting di lakukan oleh guru kepada peserta didik karena dari sebuah informasi peserta didik akan mengetahui permasalahan ataupun berita,pengumuman yang di sampaikan pihak sekolah melalui guru kepada peserta didik sehigga peserta didik mengetahu informasi terbaru yang ada di sekolah.

Guru di MTS TARBIYATUL HUDA telah menekankan kedisiplinan kelas kepada siswa, dengan mengusahakan agar siswa melaksanakan dan mentaati tata tertib yang berlaku. Berbagai upaya yang dilakukan guru mulai dari memberikan pengarahan, teguran, hukuman, dan tindakan lain yang dapat mendisiplinkan siswa. Tetapi dalam pelaksanaan kedisiplinan siswa di kelas sering terdapat kendala atau adanya permasalahan yang terjadi dalam kelas.

Dalam kasus yang terjadi di MTS TARBIYATUL HUDA terkait dengan kedisiplinan siswa ditunjukan dengan masih adanya peserta didik yang datang terlambat masuk sekolah, berpakain kurang baik, tidak mengerjakan tugas, peserta didik bolos sekolah, membuat keramaian saat pelajaran berlangsung, serta masih ada juga siswa tertentu yang menjadi biang atas keramaian siswa di kelas dan masih ada dari sebagian peserta didik yang memiliki motivasi yang rendah dalam mengikuti pembelajaran. Permasalahan kedisiplinan siswa di MTS TARBIYATUL HUDA terjadi karena peran kepemimpinan guru kurang tepat ataupun kurang sesuai dengan keadaan yang dihadapi guru disekolah tersebut. Disiplin peserta didik sangatlah penting karna itu adalah salah satu aturan untuk menjadikan peserta didik yang berkarakter baik, bertanggung jawab, dan menumbuhkan kepercayaan diri di dalam individu peserta didik. Oleh karena itu, untuk mengetahui lebih jauh tentang kepemimpinan guru terhadap disilpin belajar peserta didik di MTS TARBIYATUL HUDA, maka tindakan guru disekolah tersebut akan dilihat dan disesuaikan dengan kepemimpinan guru..

\section{MATERI DAN METODE}

\section{Jenis penelitian}

Penelitian ini menggunakan pendekatan kuantitatif, karna data yang di dapatkan berbentuk numerik atau angka. Metode penelitian kuantitatif dapat diartikan sebagai metode penelitian yang berdasarkan pada populasi tertentu, pengumpulan data menggunakan instrument penelitian, analisis data bersifat kuantitaif/statistik, dengan tujuan untuk menguji hipotesis yang telah ditetapkan. Penelitian ini bersifat hubungan fungsional yang bertujuan untuk mengetahui pengaruh variabel bebas atau lebih terhadap variabel terikat. Variabel bebas (X) disini adalah kepemimpinan guru sedangkan variabel terikat $(\mathrm{Y})$ adalah disiplin belajar peserta didik. Alat analisis yang digunakan dalam penelitian ini menggunakan analisis regresi. Sumber data diperoleh dari subyek dalam penelitian yaitu kepala madrasah, wali kelas, peserta didik,. Peneliti menggunakan teknik pengumpulan data melalui observasi, wawancara, dan dokumentasi. Populasi dalam penelitian ini yaitu seluruh peserta didik kelas VII dan kelas VIII MTS TARBIYATUL HUDA Pancawati Bogor berjumlah 133 siswa yang berasal dari yang terdiri dari 4 kelas yaitu kelas kelas VII A Putra, VII B Putra, VIII A putra, VIII B B Putra. sampel dari masing-masing populasi kelas yaitu sampel sebanyak 17 siswa dari kelas VII A PA, 18 siswa dari kelas VII B PA, 12 siswa dari kelas VIII A PA, 11 siswa dari kelas VIII B PA. Dengan demikian, sampel 
yang akan digunakan dalam penelitian ini sebanyak 58 siswa.

Kemudian, untuk mengambil anggota/siswa siapa saja dalam kelas tersebut yang akan dijadikan anggota sampel pada masing-masing jumlah sampel yang telah ditetapkan, peneliti melakukan pengambilan sampel tersebut dengan menggunakan teknik acak, angket pertanyaan di bagikan secara acak kepada peserta didik dan hanya peserta didik tertentu yang dapat menjawab yaitu peserta didik yang telah ditentukan oleh peneliti dengan cara memilih nomor absen peserta didik yang ganjil yang dibolehkan menjawab angket pertanyaan dari peneliti. Dalam penelitian ini peneliti menggunakan skala Likert dengan menggunakan kategori pilihan yaitu dengan 5 alternatif jawaban yaitu selalu, sering, kadang-kadang, pernah dan tidak pernah. Responden memilih jawaban sesuai dengan keadaannya sendiri. Pembuatan angket terlebih dahulu dengan menentukan dimensi kepemimpinan guru dan dimensi disiplin belajar menjadi indikator-indikator kemudian menjabarkan dimensi menjadi indikator-indikator kepemimpinan guru dan disiplin belajar

Waktu penelitian ini di mulai dari bulan pebruari observasi sampai menyelesaikan skipsi. Adapun tempat penilitian yaitu di MTS Tabiyatul Huda Pancawati yang beralamat Jl. Veteran I Kampung Legok Nyenang Rt. 01/09 Desa. Pancawati, Kec. Caringin, Kab. Bogor. Penelitian ini menggunakan metode pengambilan data dengan observasi, peneliti sebelum melakukan penelitian di sekolah pertama peneliti mengobservasi yaitu melihat setiap kelas, gedung sekolah dan lingkungan sekolah kemudian peneliti melakukan wawancara dengan beberapa guru di sekolah tentang kepemimpinan guru yang di lakukan di sekolah dan menanyakan juga tentang kedisiplinan para peserta didik selama mengikuti pelajaran di kelas ataupun di luar kelas. Metede wawancara, peneliti melakukan wawancara terkait judul yang akan peneliti teliti yaitu mewawancarai kepala sekolah, guru-guru, dan peserta didik setelah wawancara selesai di lakukan maka peneliti menyimpulkan dari hasil wawancara tersebut dan memasukannya kedalam latara belakang ataupun pembahasan untuk dijadikan bahan penelitian. Metode selanjutnya yaitu metode angket. Angket adalah sebuah pertanyaan atau pernyataan yang dilakukan oleh para peneliti untuk mendapatkan data dari responden. Adapun peneliti dalam hal ini menggunakan angket pertanyaan kepada peserta didik, peserta didik hanya menjawab karena jawaban dari angket sudah peneliti siapkan dari hasil penyebaran angket ini maka data yang peneliti dapatkan akan di olah menggunakan rumus spss. Metode yang terakhir yaitu dokumentasi metode ini peneliti lakukan dari mulai penelitian laksanakan peneliti meminta dokumendokumen dari kantor sekolah seperti dokumen daftar hadir guru, daftar absen siswa, daftar jumlah pendidik dan kependidikan, dan peneliti mengambil gambar lingkungan sekolah gedung sekolah, asrama putra, kelas, dan ruang kepala sekolah.

Dalam penelitian ini, peneliti menggunakan instrumen kepemimpinan guru dan disiplin belajar dengan menggunakan angket yang di dalamnya terdiri dari beberapa indikator yang menjadi aspek penilaian untuk angket ini yaitu aspek energik, stabilitas emosi, hubungan sosial, motivasi pribadi, keterampilan komunikasi, keterampilan mengajar, komponen teknis dan untuk aspek disiplin belajar yaitu Disiplin dalam 
masuk sekolah, Disiplin dalam mengikuti pelajaran di sekolah, Disiplin dalam mengerjakan tugas, Disiplin belajar di rumah, Disiplin dalam menaati tata tertib sekolah dari semua aspek tersebut dibagi lagi menjadi beberapa penilaian atau indikator yang dapat mewakili dari masingmasing penilaian tersebut, dan selanjutnya dari beberapa indikator tersebut dibuatlah pertanyaan baik pertanyaan positif maupun negatif. Keberhasilan dari sebuah penelitian adalah ditentukan dari benar atau tidaknya suatu instrument penelitian. Oleh karena itu, sebaiknya peneliti melakukan uji coba terhadap instrument yang dibuat. Instrument yang baik adalah yang memiliki dua persyaratan yaitu valid dan reliable.

\section{Uji Validitas}

Validitas adalah suatu ukuran yang menunjukan keakurasian dari suatu alat ukur. Uji validitas digunakan untuk mengetahui apakah instrument yang dibuat bisa mengukur penelitian yang dinginkan. Uji validitas dilakukan menggunakan analisis faktor yaitu dilakukan dengan cara mengkorelasikan jumlah skor faktor dengan skor total. Sebelum melakukan uji validitas, instrumen harus diujicobakan terlebih dahulu, tetapi sebelum di uji cobakan, instrumen harus memenuhi validitas konstruk terlebih dahulu, maka dari itu peneliti menggunakan teknik Expert Judgment yaitu dengan meminta penilaian ahli mengenai instrumen yang akan digunakan dalam penelitian. Ahli penelitian ini yaitu Bpk. Dr. Syamsudin Ali Nasution, MA dengan melihat kesesuaian antara kisikisi dan pertanyaan yang digunakan pada angket. Setelah angket di validasi kemudian dilakukan penyebaran uji coba angket. Uji validitas instrumen pada penelitian ini menggunakan bantuan program SPSS versi
16. Adapun rumus korelasi product moment yaitu sebagai berikut.

$\mathrm{rxy}=\frac{N \sum X Y-\left(\sum X\right)\left(\sum Y\right)}{\sqrt{\left[N \sum X^{2}-\left(\sum X\right)^{2}\right]\left[N \sum Y^{2}-\left(\sum Y\right)^{2}\right]}}$

Keterangan: $r x y=$ Angka Indeks Korelasi "r" Product Moment; $\mathrm{N}=$ Number of Cases; $\boldsymbol{\Sigma} \mathrm{XY}=$ Jumlah hasil perkalian antara skor $\mathrm{X}$ dan skor Y; $\boldsymbol{\Sigma X}=$ Jumlah seluruh skor X; $\boldsymbol{\Sigma} \mathrm{Y}=$ Jumlah seluruh skor $\mathrm{Y}$.

Instrumen dikatakan valid jika nilai $r$ hitung $>r$ tabel berdasarkan uji signifikan yaitu 0,05 .Setelah melakukan penyebaran uji coba instrumen penelitian ke 30 responden, selanjutnya dilakukan pengolahan data instrumen penelitian dengan bantuan program SPSS versi 16 yang menghasilkan data tersebut valid atau tidak valid. Korelasi yang digunakan adalah Korelasi Pearson Moment. Nilai koefisien korelasi tersebut selanjutnya dibandingkan dengan nilai $r$ tabel. Untuk taraf kesalahan $5 \%$ dan $\mathrm{dk}=\mathrm{n}-2=28$, maka diperoleh $\mathrm{r}$ tabel sebesar 0,3610. Ketika dibandingkan antara nilai koefisien korelasi ( $\mathrm{r}_{\text {hitung}}$ ) dengan nilai $r$ tabel, terdapat 21 butir pertanyaan kepemimpinan guru dengan nilai $r_{\text {hitung }}<r_{\text {tabel }}$ yaitu pada butir pernyataan ke $1,4,5,6,8,9,11,12,14,15$, $16,17,21,23,30,31,36,37,39,43$, 44, yang menunjukkan butir pertanyaan tersebut tidak valid dan tidak akan digunakan dalam pengumpulan data instrumen. Dan terdapat 19 pertanyaan disiplin belajar peserta didik dengan nilai $r_{\text {hitung }}<r_{\text {tabel }}$ yaitu pada butir pertanyaan ke $1,4,5,6,8,9,11,12,14,15$, $16,17,21,23,30,31,36,37,39$, yang menunjukan butir pertanyaan tersebut tidak valid dan tidak akan digunakan dalam pungumpulan data instrument. Setelah dilakukan validitas instrument selanjutnya peneliti menggunakan uji reabilitas.

\section{Uji Reliabilitas}

Reliabilitas adalah konsistensi atau kesetabilan skor suatu instrument penelitian terhadap individu yang sama, dan 
diberikan dalam waktu yang berbeda. Instumen yang reliabel berarti instrumen yang bila digunakan beberapa kali untuk mengukur obyek yang sama, akan menghasilkan data yang sama. Untuk menguji tingkat kepemimpinan guru peneliti menggunakan bantuan program SPSS versi 16. Adapun rumus Cronbach Alpha yaitu:

Keterangan: $\mathrm{k}=$ Jumlah butir dalam skala pengukuran; $\mathrm{S}^{2}{ }_{\mathrm{i}}=$ Ragam (variance) dari butir ke- $I$; $\mathrm{S}^{2} \mathrm{p}=$ Ragam (variance) dari skor total.

Kriteria uji instrumen dengan Cronbach Alpha yaitu jika nilai Alpha > 0,60 maka instrumen tersebut reliabilitas. Adapun hasil dari perhitungan reabilitas kepemimpinan guru untuk Cronbach Alpha dengan menggunakan Spss 16 seperti pada Tabel 1.

Tabel 1 Hasil perhitungan uji reliabilitas kepemimpinan guru

\begin{tabular}{cr}
\hline Cronbach's Alpha & N of Items \\
\hline .778 & 25 \\
\hline
\end{tabular}

Terlihat pada tabel 1 diperoleh koefisien Cronbach Alpha dari instrument kepemimpinan guru sebesar 0,778. Hal tersebut menunjukkan bahwa koefisien Cronbach Alpha lebih besar dari standar koefisien Cronbach Alpha. Hal tersebut dapat disimpulkan bahwa jika nilai Cronbach Alpha lebih besar dari standar Cronbach Alpha maka data tersebut dikatakan reliabel. Pada data tersebut diperoleh 0,778 > 0,60 yang menunjukkan bahwa data tersebut bersifat reliable. Adapun hasil dari perhitungan reabilitas disiplin belajar untuk Cronbach Alpha dengan menggunakan Spss 16 seperti pada Tabel 2.
Tabel 2 Hasil perhitungan uji reliabilitas disiplin belajar

Cronbach's Alpha N of Items

.728

21

Terlihat pada tabel 2 diperoleh koefisien Cronbach Alpha dari instrument disiplin belajar sebesar 0,728. Hal tersebut menunjukkan bahwa koefisien Cronbach Alpha lebih besar dari standar koefisien Cronbach Alpha. Hal tersebut dapat disimpulkan bahwa jika nilai Cronbach Alpha lebih besar dari standar Cronbach Alpha maka data tersebut dikatakan reliabel. Pada data tersebut diperoleh $0,728>0,60$ yang menunjukkan bahwa data tersebut bersifat reliable. Dalam bukunya Kurniawan data yang peneliti oleh melalui spss adalah data yang peneliti dapatkan dari sebaran angket kepada peserta didik di sekolah MTs Al-Muhctari Cimande. Kemudian hasil dari jumlah kuisioner atau pertanyaan yang telah di validasi kepemimpinan guru 25 pertanyaan dan disiplin belajar 21 pertanyaan, dari hasil pertanyaan yang valid ini akan di sebarkan ke sampel responden yaitu peserta didik MTs Tarbiyatul Huda yang berjumlah 58 peserta didik dari 4 kelas.

Dari hasil pengolahan melalui spss mengenai validitas dan reabilitas maka selanjutnya peneliti melakukan analisis deskriptif. Analisis deskriptif ini bertujuan untuk memberikan gambaran terhadap objek yang diteliti melalui data sampel atau populasi tanpa melakukan analisis dan tanpa membuat kesimpulan yang berlaku umum. Analisis deskriptif juga digunakan untuk menggambarkan mengenai ringkasan data penelitian seperti mean, minimum, 
maximum, standar deviasi, modus, dan yang lain-lain. Adapaun dalam penelitian ini deskriptif digunakan untuk mengetahui kepemimpinan guru dan disiplin belajar peserta didik di MTs Tarbiyatul Huda. Setalah dilakukan uji deskriptif kemudian peneliti melakukan uji prasarat Analisis. Uji prasyrat analisi bertujuan untuk menguji apakah data yang terkumpul telah memenuhi prasyarat untuk dianalisis atau tidak. Adapun uji prasyarat meliputi uji normalitas dan uji linearitas. Uji normalitas adalah uji yang digunakan untuk mengetahui populasi data berdistribusi normal atau tidak.

Dalam penelitian ini peneliti menggunakan uji Kolmogorof-Smirbov dengan bantuan program Spss versi 16 untuk menghitung normalitas data kedua variabel yaitu kepemimpinan guru dan disiplin belajar peserta didik dan data dinyatakan berdistribusi normal jika signigfikansi lebih besar dari 0,05. Uji lenearitas digunakan untuk melihat garis regresi anatara kepemimpinan guru dan dsiplin belajar peserta didik membentuk garis linear atau tidak. Pengujian linearitas dilakukan menggunakan bantuan Spss versi 16. Dan dari dua variabel dikatakan mempunyai hubungan linear, apabila nilai signifikansi kurang dari 0,05.

\section{HASIL DAN PEMBAHASAN}

Berdasarkan penelitian yang dilakukan di MTS Tarbiyatul Huda Pancawati Bogor bahwa ada pengaruh yang signifikan kepemimpinan guru terhadap disiplin belajar peserta didik MTS Tarbiyatul Huda Pancawati Bogor. Nilai pengaruh positif dapat dilihat pada fungsi regresi sederhana.
Berdasarkan hasil perhitungan, diketahui nilai beta satu (b) sebesar 0,969 artinya setiap penambahan satu angka pada variabel X maka terjadi kenaikan sebesar 0,969 pada variabel $Y$, maka dapat disimpulkan bahwa nilai pengaruh yang diberikan kepada variabel $\mathrm{Y}$ oleh variabel $\mathrm{X}$ bersifat positif. Berdasarkan hasil persamaan regresi tersebut, maka dapat diprediksi bahwa semakin baik kepemimpinan guru, maka akan semakin tinggi pula disiplin belajar peserta didik tersebut, dan sebaliknya.

Berdasarkan perhitungan dengan menggunakan program SPSS versi 16, hasil penelitian mengenai variabel kepemimpinan guru dapat dilihat dari data pada Tabel 3.

Tabel 3 Statistik deskriptif variabel $\mathrm{X}$ (kepemimpinan guru)

\begin{tabular}{llr}
\hline 1 & Jumlah data & 58 \\
2 & Mean & 135.55 \\
3 & Standar Deviation & 18.636 \\
4 & Minimum & 99 \\
5 & Maximum & 175 \\
\hline
\end{tabular}

a. Setelah data diurutkan dari yang terkecil sampai yang terbesar kemudian menghitung jarak atau rentangan (R).

$\mathrm{R}=$ data tertinggi - data terendah

$\mathrm{R}=175-99=76$

b. Hitung jumlah kelas (K) dengan Sturges

$\mathrm{K}=1+3,3 \log$. $(\mathrm{N})$

$\mathrm{K}=1+3,3 \log (58)=6.8$ dibulatkan $=7$

c. Hitung panjang kelas interval (P)

$\mathrm{P}=\frac{\operatorname{Rentang}(R)}{\text { Jumlah Kelas }(K)}$

$\mathrm{P}=\frac{76}{7}=10.85$ dibulatkan $=\mathbf{1 1}$

d. Membuat tabel distribusi frekuensi (lihat Tabel 4) 
Tabel 4 Distribusi frekuensi variabel $\mathrm{X}$ (kepemimpinan guru)

\begin{tabular}{lcrr}
\hline No & $\begin{array}{c}\text { Nilai } \\
\text { Interval }\end{array}$ & $\begin{array}{c}\text { Frekuensi } \\
\text { (f) }\end{array}$ & $\begin{array}{c}\text { Frekuensi } \\
\text { (Frelatif) }\end{array}$ \\
\hline 1 & $99-109$ & 5 & $5 \%$ \\
2 & $110-120$ & 9 & $9 \%$ \\
3 & $121-131$ & 13 & $13 \%$ \\
4 & $132-142$ & 8 & $8 \%$ \\
5 & $143-153$ & 12 & $12 \%$ \\
6 & $154-164$ & 8 & $8 \%$ \\
7 & $165-175$ & 3 & $3 \%$ \\
\hline
\end{tabular}

Penyajian data distribusi frekuensi variabel X (Kepemimpinan Guru) dalam bentuk grafik histogram dapat dilihat pada gambar 1.

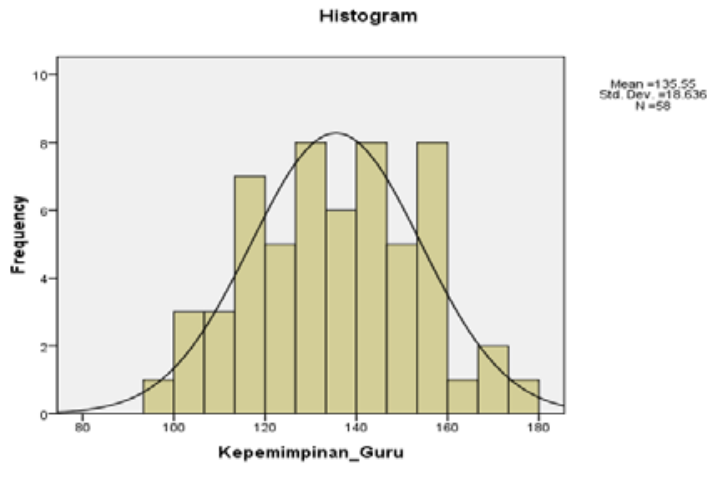

Gambar 1 Histogram variabel X

Grafik histogram di atas menggambarkan normalitas data, dapat dilihat pada garis kurva yang membentuk seperti gunung, sehingga dapat dikatakan data berdistribusi normal. Menentukan kualifikasi kepemimpinan guru dengan menentukan kelas yang dikategorikan menjadi 3 kategori seperti pada Tabel 5 .

Tabel 5 Nilai distribusi frekuensi variabel X (kepemimpinan guru)

\begin{tabular}{cccrll}
\hline No & Nilai Interval & F & Presentase & \multicolumn{1}{c}{ Keterangan } & Kualitas \\
\hline 1 & $99-109$ & 16 & $16 \%$ & Kurang baik & \\
2 & $125-150$ & 29 & $29 \%$ & Baik & Baik \\
3 & $151-176$ & 11 & $11 \%$ & Sangat Baik & \\
& Jumlah & & $58 \%$ & & \\
\hline
\end{tabular}

Berdasarkan tabel 5, dapat disimpulkan bahwa data kepemimpinan guru di MTS Tarbiyatul Huda masuk ke dalam kategori cukup baik dengan jumlah presentase sebesar $29 \%$ yang terletak pada interval 125 - 176 dari 58 jumlah responden. Berdasarkan perhitungan dengan program SPSS versi 16, hasil penelitian mengenai variabel disiplin belajar dapat dilihat dari data pada Tabel 6 .

Tabel 6 Statistik deskriptif variabel Y (prestasi belajar)

\begin{tabular}{ll}
\hline $\mathrm{N}$ & 58 \\
Mean & 117.55 \\
Standar Deviation & 18.093 \\
Minimum & 83 \\
Maximum & 155 \\
\hline
\end{tabular}

a. Hitung jarak atau rentangan (R)

$\mathrm{R}=$ data tertinggi - data terendah

$\mathrm{R}=155-83=72$

b. Hitung jumlah kelas (K) dengan Sturges

$\mathrm{K}=1+3,3 \log \cdot(\mathrm{N})$

$\mathrm{K}=1+3,3 \log (58)=6.8$ dibulatkan $=7$

c. Hitung panjang kelas interval (P)

$\mathrm{P}=\frac{\text { Rentang }(R)}{\text { Jumlah kelas }(K)}$

$\mathrm{P}=\frac{72}{7}=10,28$ dibulatkan $=10$

d. Membuat tabel distribusi frekuensi (lihat Tabel 7)

Adapun penyajian data distribusi variabel Y (Prestasi Belajar) dalam bentuk grafik histogram dapat dilihat pada gambar 2. 
Tabel 7 Distribusi frekuensi variabel Y (prestasi belajar)

\begin{tabular}{lcrr}
\hline No & $\begin{array}{c}\text { Nilai } \\
\text { Interval }\end{array}$ & $\begin{array}{c}\text { Frekuensi } \\
\text { (f) }\end{array}$ & $\begin{array}{c}\text { Frekuensi } \\
(\text { Frelatif })\end{array}$ \\
\hline 1 & $83-92$ & 5 & $5 \%$ \\
2 & $93-102$ & 9 & $9 \%$ \\
3 & $103-112$ & 9 & $9 \%$ \\
4 & $113-122$ & 10 & $10 \%$ \\
5 & $123-132$ & 12 & $12 \%$ \\
6 & $133-142$ & 9 & $9 \%$ \\
7 & $143-152$ & 2 & $2 \%$ \\
8 & $153-162$ & 2 & $2 \%$ \\
\hline
\end{tabular}

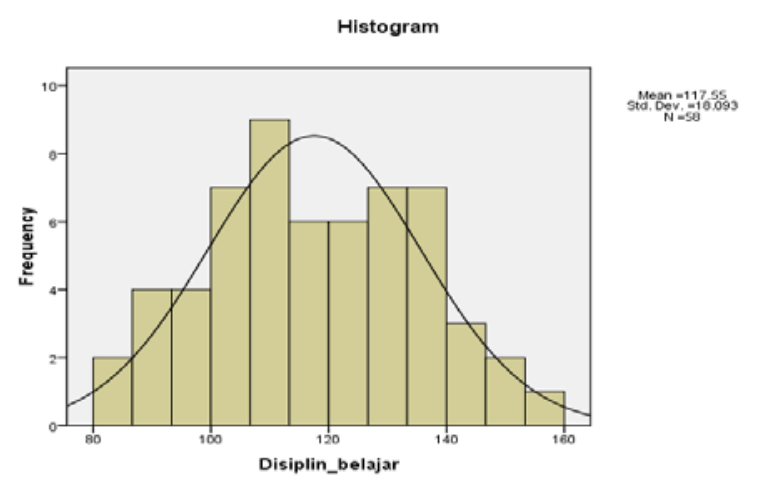

Gambar 2 Histogram variabel Y (disiplin belajar)

Grafik histogram di atas menggambarkan normalitas data, dapat dilihat pada garis kurva yang membentuk seperti gunung, sehingga dapat dikatakan data berdistribusi normal. Menentukan kualifikasi prestasi belajar dengan menentukan kelas yang dikategorikan menjadi 3 kategori yang dapat dilihat pada Tabel 8.

Berdasarkan tabel 8, dapat disimpulkan bahwa data disiplin belajar peserta didik di MTS Tarbiyatul Huda masuk ke dalam kategori cukup baik dengan jumlah presentase sebesar $25 \%$ yang terletak pada interval 25 - 127 dari 58 jumlah responden. Berdasarkan hasil uji normalitas di atas, diketahui bahwa nilai signifikansi untuk Kepemimpinan guru sebesar 0,929 dan nilai signifikansi untuk Disiplin belajar sebesar 0,967. Karena signifikansi dari kedua variabel lebih besar dari 0,05, maka dapat disimpulkan bahwa data yang peneliti uji berdistribusi normal. Berdasarkan hasil uji linearitas di atas, diketahui bahwa nilai signifikansi pada Deviation from Linearity sebesar 0,634 yang menunjukkan bahwa nilai signifikansi tersebut lebih besar dari 0,05, sehingga dapat disimpulkan bahwa antara variabel kedisiplinan belajar dan prestasi belajar terdapat hubungan yang linear.

Tabel 8 Nilai distribusi frekuensi variabel Y (disiplin belajar)

\begin{tabular}{|c|c|c|c|c|c|}
\hline No & Nilai Interval & $\mathrm{F}$ & Presentase & Keterangan & Kualitas \\
\hline 1 & $83-107$ & 20 & $20 \%$ & Kurang baik & \multirow{4}{*}{ Baik } \\
\hline 2 & $108-132$ & 25 & $25 \%$ & Baik & \\
\hline 3 & $133-157$ & 13 & $13 \%$ & Sangat baik & \\
\hline & Jumlah & 53 & $53 \%$ & & \\
\hline
\end{tabular}

Berdasarkan perhitungan menggunakan program SPSS versi 16 dapat diperoleh nilai a (constant) sebesar 13.789 dan nilai b (koefisien regresi) sebesar 0,969 Dalam perhitungan persamaan regresi ini diperoleh nilai persamaan regresi $Y=13.789$ $+0,969$ X. Pada tabel di atas diperoleh $t_{\text {hitung }}$ sebesar 117.884 dengan taraf kesalahan 5\% uji dua pihak dan dk =n-2 atau dk $=58-2=$ 52, maka diperoleh $t_{\text {tabel }}=1,672$. Nilai tersebut menunjukkan bahwa $t_{\text {hitung }}>t_{\text {tabel }}$ (117.884 > 1,672), maka $\mathrm{H}_{0}$ ditolak, sehingga dapat disimpulkan terdapat pengaruh positif yang signifikan kepemimpinan guru terhadap disiplin belajar peserta didik. Jadi, semakin baik kepemimpinan guru maka semakin baik pula disiplin belajar peserta didik.

Berdasarkan perhitungan menggunakan program SPSS versi 16 diperoleh nilai $\mathrm{R}$ Square $\left(\mathrm{r}^{2}\right)$ sebesar 0,996. Sesuai dengan rumus $\mathrm{KD}=0,996 \times 100 \%=99,6 \%$. Hal ini menunjukkan varian yang terjadi pada variabel disiplin belajar (Y) ditentukan oleh 
kepemimpinan guru (X). Jadi, dapat diambil kesimpulan bahwa disiplin belajar dipengaruhi oleh kepemimpinan guru sebesar 99,6\% sedangkan selebihnya sebesar $0.4 \%$ dipengaruhi oleh faktor lain. Uji t digunakan untuk mengetahui tingkat signifikansi serta untuk menguji ada

Tabel 9 Hasil uji t tidaknya pengaruh variabel bebas (X) terhadap variabel terikat (Y). Dalam penelitian ini peneliti menggunakan apliaksi SPSS versi $d 16$ dengan syarat $t_{\text {hitung }}>t_{\text {tabel }}$ dengan nilai signifikansi $<0,05$. Adapun hasilnya seperti pada Tabel 9 .

Coefficients

\begin{tabular}{|c|c|c|c|c|c|c|}
\hline \multirow{2}{*}{\multicolumn{2}{|c|}{ Model }} & \multicolumn{2}{|c|}{ Unstandardized Coefficients } & \multirow{2}{*}{$\begin{array}{c}\begin{array}{c}\text { Standardized } \\
\text { Coefficients }\end{array} \\
\text { Beta } \\
\end{array}$} & \multirow[t]{2}{*}{$\mathrm{t}$} & \multirow{2}{*}{ Sig. } \\
\hline & & B & Std. Error & & & \\
\hline & (Constant) & 13.789 & 1.124 & & -12.263 & .000 \\
\hline & Kepemimpinan_Guru & .969 & .008 & .998 & 117.884 & .000 \\
\hline
\end{tabular}

a. Dependent Variable: Disiplin_Belajar

Berdasarkan tabel 9, diperoleh nilai thitung sebesar 117.884 yang lebih besar dari tabel 1,672 yang berarti $\mathrm{H}_{0}$ : ditolak, dan $\mathrm{H}_{1}$ : diterima yang menunjukkan adanya pengaruh keepemimpinan guru terhadap disiplin belajar. Kemudian untuk mengetahui tingkat signifikansi dilakukan dengan melihat nilai Sig. yaitu sebesar 0,000 yang memiliki nilai $<0,05$ yang berarti variabel $\mathrm{X}$ memiliki pengaruh yang signifikan terhadap varaibel Y. Dari hasil penelitian dapat dibandingkan dengan penelitian relavan yang di lalakukan oleh Muhsin dengan judul kepemimpinan guru terhadap motivasi belajar yang menunjukan bahwa ada pengaruh positif pada kepemimpinan guru terhadap motivasi belajar siswa. Hal ini sama dengan penelitian yang di lakukan oleh peneliti bahwa ada pengaruh kepemimpinan guru terhadap disiplin belajar peserta didik.

Adapun faktor yang menjadikan kepemimpina guru di MTS Tarbiyatul Huda berkatagori baik yaitu faktor kinerja guru dalam mengajar, faktor kedisiplinan guru dalam peraturan sekolah dan demokratis guru di tarbiyatul huda dalam memecahkan suatu masalah di sekolah. Kemudian faktor disiplin belajar peserta didik berkatagori baik yaitu karan dua faktor yaitu faktor internal dari seorang peserta didik yang memiliki kesadaran yang baik terhadap aturan-aturan yang di tetapkan oleh sekolah, faktor eksternal yaitu sansi dan hukuman. Adanya pengaruh yang signifikan kepemimpinan terhadap disiplin belajar mendukung teori-teori yang telah dikemukakan sebelumnya. Hal ini sesuai dengan yang dikemukakan oleh Sudirman Danim dalam bukunya Kepemimpinan Pendidikan bahwa Kepemimpinan adalah seni mempengaruhi orang lain. Seorang pemimpin adalah jenis manusia yang bisa mempengaruhi orang lain sehingga mengikuti apa yang dia kehendaki. Kualitas kepemimpinan seseorang dinilai dari sebesar apa pengaruh dia terhadap orang lain. Semakin besar pengaruh seorang pemimpin, maka semakin hebat kepemimpinannya. Hal ini juga sesuai dengan pendapat Irman Suherman dalam bukunya Kepemimpinan Pendidikan bahwa kepemimpinan dalam sebuah sekolah sangat penting adanya, karena berfungsi sebagai jangkar, memberikan panduan pada masa-masa perubahan dan bertanggung 
jawab atas efektifitas sekolah. Doni Juni Priansa mengemukakan bahwa kepemimpinan di bangun atas dasar profesionalisme dan kesejawatan.

Dari hasil penelitian dapat dibandingkan dengan penelitian relavan yang di lalakukan oleh Muhsin dengan judul kepemimpinan guru terhadap motivasi belajar yang menunjukan bahwa ada pengaruh positif pada kepemimpinan guru terhadap motivasi belajar siswa. Hal ini sama dengan penelitian yang di lakukan oleh peneliti bahwa ada pengaruh kepemimpinan guru terhadap disiplin belajar peserta didik. Adapun faktor yang menjadikan kepemimpina guru di MTS Tarbiyatul Huda berkatagori baik yaitu faktor kinerja guru dalam mengajar, faktor kedisiplinan guru dalam peraturan sekolah dan demokratis guru di tarbiyatul huda dalam memecahkan suatu masalah di sekolah. Kemudian faktor disiplin belajar peserta didik berkatagori baik yaitu karan dua faktor yaitu faktor internal dari seorang peserta didik yang memiliki kesadaran yang baik terhadap aturan-aturan yang di tetapkan oleh sekolah, faktor eksternal yaitu sansi dan hukuman.

Penjabaran di atas menunjukkan bahwa secara teoritis kedisiplinan mempunyai pengaruh terhadap disiplin belajar peserta didik. hal tersebut dibuktikan dengan analisis data dalam penelitian ini yang menunjukkan bahwa hasil uji $\mathrm{t}$ sebesar 117,884 dengan signifikansi 0,000 (signifikan) dan persamaan regresi yang menunjukkan nilai positif. Selain itu, diketahui bahwa nilai sumbangan kedisiplinan terhadap prestasi belajar siswa sebesar 99,6 \% dan sisanya $0,4 \quad \%$ dipengaruhi faktor lain. Oleh karena itu, dapat disimpulkan hasil penelitian ini mendukung teori yang telah dikemukakan sebelumnya, yaitu adanya pengaruh signifikan kepemimpinan guru terhadap disiplin belajar peserta didik di MTS Tarbiyatul Huda Pancawati Bogor.

\section{KESIMPULAN DAN IMPLIKASI}

Berdasarkan hasil penelitian tentang pengaruh kepemimpinan guru terhadap disiplin belajar di MTS Tarbiyatul Huda Bogor, maka peneliti memberikan kesimpulan sebagai berikut:

1. Tingkat kepemimpinan guru di MTS Tarbiyatul Huda Bogor Tergolong baik dengan mean sebesar 135.55 ) yang terletak pada interval 125 - 150 dengan presentase $29 \%$ dari jumlah 58 responden.

2. Disiplin belajar peserta didik di MTS Tarbiyatul Huda Bogor tergolong dalam kategori baik dengan mean 117.55 yang terletak pada interval 108 - 132 dengan presentase sebesar $25 \%$ dari jumlah 58 responden.

3. Adanya pengaruh yang positif dan signifikan kepemimpinan guru terhadap disiplin belajar peserta didik di MTS Tarbiyatul Huda Bogor. Hal ini dibuktikan dengan hasil persamaan regresi dengan nilai positif sebesar $\mathrm{Y}=$ $13.789+0,969 \quad X$ dan memiliki sumbangan nilai $\mathrm{R}$ Square yaitu 0,996 atau $99,6 \%$. Artinya besaran sumbangan faktor kedisiplinan terhadap prestasi belajar sebesar 99,6\%, sedangkan sisanya sebesar $0,04 \%$ dipengaruhi oleh faktor lain. Selain itu, hasil pengujian hipotesis dengan uji $t$ menunjukkan bahwa hipotesis yang diajukan diterima. Hal ini ditunjukkan dengan hasil thitung > tabel yakni $117.884>1,672$ dan hasil signifikansi yang lebih kecil dari 0,05 yaitu 0,000 . 
Tadbir Muwahhid ISSN 2579-4876 e-ISSN 2579-3470 Volume 2 Nomor 2, Oktober 2018 | 155

\section{DAFTAR PUSTAKA}

Danim, S, (2012). Kepemimpinan Pendidikan. Bandung: Alfabeta

Juni, Doni, P, 2014 Kinerja dan Profesionalisme Guru. Bandung: Alfabeta Kurniawan, A. (2009). Belajar Mudah SPSS untuk Pemula. Yogyakarta: MediaKom
Mulyasa. 2016. Menjadi Guru Profesional Bandung: Remaja Rosda Karya

Muhsin. (2008). "Pengaruh Kepemimpinan dan Komunikasi Guru Terhadap Motivasi Belajar". Jurnal Pendidikan Ekonomi, 3(2). 